\begin{tabular}{|c|c|}
\hline OPEN & Available on line at Directory of Open Access Journals \\
\hline JOURNAL & Journal of Hyperspectral Remote Sensing v.8, n.2 (2018) 78-84 \\
\hline SYSTEMS & www.periodicos.ufpe.br/revistas/jhrs \\
\hline
\end{tabular}

Journal of Hyperspectral Remote Sensing

\title{
Average insolation interpolated by the krigagem method for the state of Pernambuco - Brazil
}

\author{
Marcelo Kozmhinsky*, Raimundo M. de Medeiros ${ }^{* *}$, Romildo M. de Holanda***, Vicente de P. Silva***** \\ *MSc in Environmental Engineering; Federal Rural University of Pernambuco-UFRPE, Recife-PE, E-mail: \\ marcelok1963@gmail.com (Corresponding author) \\ ** Prof., Post-Doc., Dr. Adelmar Rosado School, Teresina-PI, E-mail: mainarmedeiros@gmail.com \\ ***Prof. Dr. Federal Rural University of Pernambuco-UFRPE, Recife-PE, E-mail: romildomorant@gmail.com \\ ***** Prof. Dr. Federal Rural University of Pernambuco-UFRPE, Recife-PE, E-mail: vicenteufrpe @ yahoo.com.br
}

Received 30 August 2018; accepted 30 September 2018

\begin{abstract}
The objective of this study was to characterize the climatic conditions of insolation in the State of Pernambuco through interpolation, elaborating maps representative of the monthly and annual distribution, besides the low variability and high insolation by the kriging method for the period 1962 to 2016. The data of insolation used Were provided by the National Institute of Meteorology (INMET), comprising the same period of study. The development of this paper was based on simplified statistical data for eight municipalities that compose the INMET meteorological network. The records indicate the incidence of sunshine above normal patterns in the hinterland and high sertão, conditioned by low cloud cover, temperature fluctuations above normal and occurrences of fires. The method of interpolation of the insolation data by the kriging model indicated optimal levels of significance when extended to the other regions of Pernambuco showing similar climatic conditions to the values used of the stations worked. The kriging of monthly and annual insolation data and the low and high sunshine months served to compose the spatial distribution maps being an alternative to generate reliable estimates with maps of greater representativity.

Keywords: basic statistics, climatological applications, variability, availability.
\end{abstract}

\section{Introduction}

According to Santos (2014), the main modulator of atmospheric dynamics is solar radiation that provides energy for the movements that drive the atmospheric circulation, it supplies with energy all the living beings of the planet, as the photosynthesis of the plants and the photovoltaic cells used in the conversion of the solar rays in electrical.

According to Brito et al. (2007) the climate of the Brazilian Northeast is complex and it is possible to find some geographical mesoregions, whose climates extend from the superhumid of the coastal zones to the dry climate of the sertão, a region known as Semiarido Nordestino. In the semi-arid region, these areas are characterized by a negative water balance, a result of average annual rainfall of less than $800 \mathrm{~mm}$, average sunshine of 2,800 hours per year, average annual temperatures of $23{ }^{\circ} \mathrm{C}$ to 27 ${ }^{\circ} \mathrm{C}$, evaporation of $2,000 \mathrm{~mm}$ per year and relative humidity around 50\% (Brito et al., 2007).

The Northeast region of Brazil (NEB) has a semi-arid climate with diverse spatial and temporal variability of rainfall, with high rates of evaporation according to Albuquerque et al. (2009). According to the authors Souza Filho and Moura (2006), climatic fluctuations have a significant impact on the socioeconomic sector, such as lack of water for planting, low-yielding seed production, stockbreeding of livestock, poultry and apiculture, degradation of the quality of life of the inhabitants of this region, diseases among others.

Sunshine is defined as the duration of the daylight period and/or the duration of the sunshine. The sunshine is important in climatic procedures, and all climatic variables are the subject of research, especially related to agriculture, according to Sousa, Silva and Ceballos (2003).

The desert regions are those that receive the greatest solar resource, as well as the areas located in the NEB semi-arid that have values of solar radiation comparable to the world desert regions according to Chigueru Tiba et al. (2000).

Sediyama (1996) has shown strategies that assess the need for water that affect the planning and implementation of programs that favor local and/or regional development based on the use of water resources.

Bayer (2004) and Bley Jr. (1999) stated that tropical environments are distinguished by the high incidence of solar radiation, temperature and sunshine, ensuring that near the equator the incidence 
is high in the North, Northeast and Central West regions of Brazil.

Kriging is a geostatistical method of estimating variable values scattered in space and / or time, with support for adjacent data considered interdependent by variographic analysis according to the authors Pires and Strieder (2006). Geostatistical techniques can be used to describe and provide spatial patterns, as well as to predict values in places not sampled according to Andriotti (2009). Yamamoto and Landin. (2015) assert that geostatistical estimation aims at modeling the spatial phenomenon, that is, determining the temporal space variability and distribution.

The kriging method differs from other interpolation methods by the way the weights are assigned. According to Yamamoto and Landin (2015), in order to understand the spatial variation of the underlying random process, one must take into account the possibility that the value at each point in space is related to values obtained at points located at a certain distance, that the influence is greater the smaller the distance between the points.

Geostatistical techniques can be used to describe and model spatial patterns in order to predict values in non-sampled locations and / or regions, according to Andriotti (2009).

The objective of this study is to characterize the climatic conditions of insolation in the State of Pernambuco and to perform its interpolation, elaborating maps representative of the monthly and annual distribution besides the variabilities of high and low insolation by the kriging method for the period 1962 to 2016.

\section{Material and methods}

The State of Pernambuco is located in the center-east of the Northeast region and has as boundaries to the north the state of Paraíba, to the northwest it borders with the state of Ceará, in the southeast position with Alagoas, Bahia in the south position and Piauí a west, in addition to being bathed by the Atlantic Ocean in the eastern sector, occupying an area of $98,937.8 \mathrm{~km}^{2}$. The archipelagos of Fernando de Noronha, São Pedro and São Paulo are part of its territory.

Being one of the smallest states of Brazil in territorial extension, Pernambuco has great diversity of landscapes: plateaus, mountains, swamps, semiarid and beautiful beaches. The most regular relief, in the coastal plain and as it moves to the interior of the state, are peaks of mountains surpassing the 1,000 meters of altitude.

The vegetation cover is very diverse, with forests, mangroves and savannas, besides a strong presence of caatinga. The coastal vegetation predominates in areas near the ocean, being coconut trees, mangroves and, in some cases, shrubs. The tropical forest is where there was originally Mata Atlântica. Few remnants of this important Brazilian biome remained. In the agreste and in the hinterland Pernambuco predominates the vegetation of caatinga. As for hydrography, there are many rivers, mainly in the Metropolitan Region of Recife, which covers 14 municipalities. The main rivers of the state are Capibaribe, Beberibe, Ipojuca, Una, Pajeú, Jaboatão and São Francisco, the latter being extremely important in the development of the sertão, since it allows the distribution of water to regions affected by drought.

In the state of Pernambuco, three climatic characteristics are identified: of the type AS in greater proportion, $\mathrm{BSH}$ in intermediate scale and the climate type Am in smaller scale.

The meteorological systems that cause and / or inhibit rainfall for the state of Pernambuco are: those that contribute moderate to weak rainfall are the vestiges of the Frontal Systems in the southern sector of the state, Convergence of the South Atlantic (SACZ), besides the formations of the convective agglomerates and the contribution of the High of Bolivia. The Intercropical Convivience Zone (ITCZ), the disturbance associated with the expansion to the southern hemisphere of the thermal equator (the heat rise zone of the Alísios by thermal convection) causes moderate to strong rains in almost the entire northern part of the State, followed by of the contributions of the Formations of the High Level Cyclonic Vortices (VCAN), the Eastern Undulating Disturbances and the Sea and Land Breezes, the latter originating in the Atlantic Ocean. Este waves are common in autumn/winter, aided by southeast trade winds, when they reach the eastern coast of the Northeast causing heavy rains, another rainfall inducer in accordance with Figure 1.

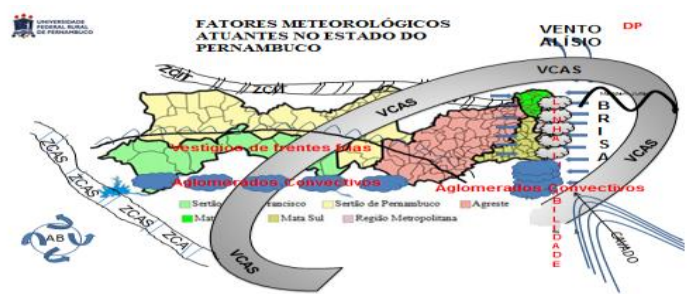

Figure 1. Illustrations of the meteorological factors in the state of Pernambuco. Source: Medeiros (2016).

The insolation data used were provided by the National Institute of Meteorology (INMET, 2016), covering the period from 1962 to 2016. This article was developed with the simplified statistical parameters data of the eight municipalities that compose the INMET meteorological network according to the Table 1 . 
Table 1. Municipalities and their geographical locations where INMET operates conventional meteorological stations.

\begin{tabular}{lccc}
\hline Counties & $\begin{array}{c}\text { Longitude } \\
\text { o' } \mathrm{W}\end{array}$ & $\begin{array}{c}\text { Latitude } \\
{ }^{\circ} \text { 'S }\end{array}$ & $\begin{array}{c}\text { Altitude } \\
\mathrm{m}\end{array}$ \\
\hline Arcoverde & 3705 & 843 & 680,7 \\
Cabrobó & 39,33 & 8,51 & 341,5 \\
Garanhuns & 36,51 & 8,88 & 822,8 \\
Ouricuri & 40,05 & 7,90 & 459,3 \\
Petrolina & 4048 & 938 & 370,5 \\
Recife & 34,95 & 8,05 & 10,0 \\
Surubim & 35,71 & 7,83 & 418,3 \\
Triunfo & 38,11 & 7,81 & 1105,0 \\
\hline
\end{tabular}

From these municipalities, the kriging interpolation method was used to aid in the responses to sunshine calculations throughout the study area.

\section{Results and discussion}

Figures (2 to 17) demonstrate the monthly and annual spatial variabilities of high and low intensity, higher and lower interpolated sunshine for the period from 1962 to 2016 in the State of Pernambuco, where distances from the point of origin receive low to high value.

Figure 2 represents the distribution of insolation interpolated by the kriging method for the month of January in the period 1962-2016. We

highlight the central and northern regions of the state with the highest variation in the incidence of sunshine with oscillation between 234 and 240 hours/month. In the southeast and southwest positions have the lowest values of sunshine incidence.

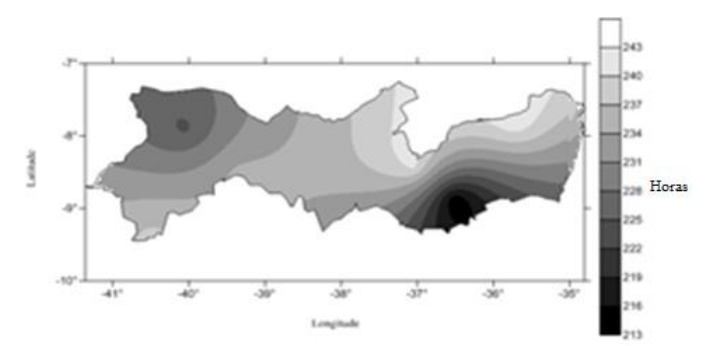

Figure 2. Insolation of the month of January in the State of Pernambuco.

In the month of February according to Figure 3 , it is observed that in the south-west position it focuses the lowest concentrations of insolation, as well as in the southeast position. In the central and northern part of the state, there are the highest occurrences of sunshine as well as part of the northern forest region. This month, the coastal area receives sunshine above normal.

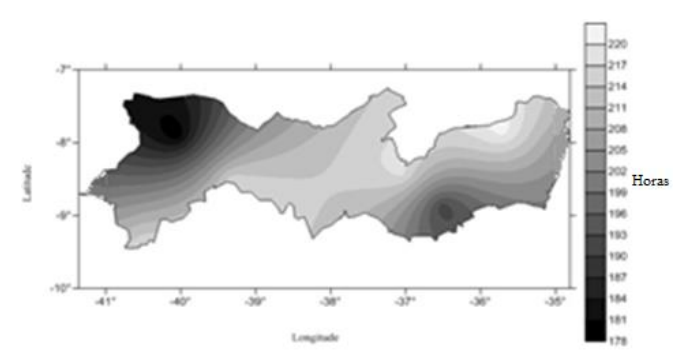

Figure 3. Insolation of the month of February in the State of Pernambuco.

Figure 4 shows the variability of the sunshine in the month of March in the period from 1962 to 2016 interpolated by the kriging method. In the southwest and southeast sectors there are the lowest incidence of sunshine and in the coast, sunshine ranges from 204 to 221 hours / month. In the northern region and part of the central region the highest concentration of insolation occurs. The variabilities are in line with the pre-season rains and their characterizations, as it increases the cloud cover and reduces the entrance of insolation directly on the earth's surface.

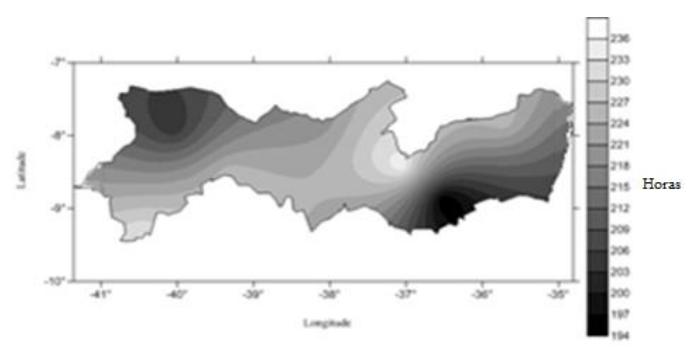

Figure 4. Insolation of the month of March in the State of Pernambuco.

Observing Figure 5 corresponding to the month of April in the period 1962-2016, it is noteworthy that in the central region, north and all southern part of the state of Pernambuco there are above-normal insolations with variations between 206 and 230 hours/ month, while that in the forest and coastal zone the incidence of sunshine varies from 176 to 196 hours/month. 


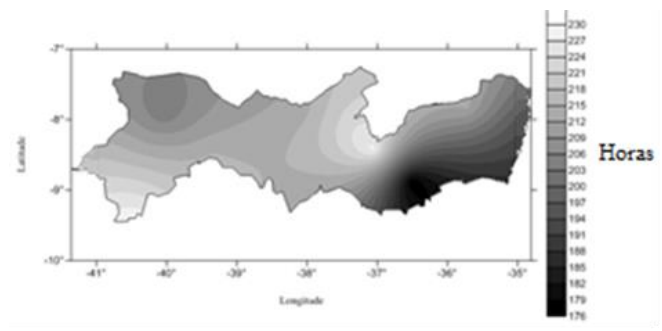

Figure 5. Insolation of the month of April in the State of Pernambuco.

The month of May shows variability fluctuating between 160 and 223 hours of insolation in the entire Pernambuco area. The lowest index of interpolated sunshine is concentrated in the southern forest region and in the northern sector. In the southwestern sector of the state there is monthly variability flowing between 200 and 206 hours of sunshine and in the southern extreme the highest sunshine rates occur (Figure 6).

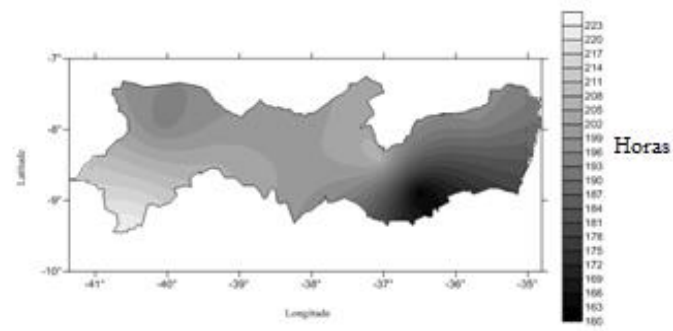

Figure 6. Insolation of the month of May in the State of Pernambuco.

The Figure 7 corresponds to the estimated solar insolation variability for the month of June in the State of Pernambuco. It is noteworthy that the highest incidence of sunshine occurs in the central part and in the extreme south of the western region. In the areas of the north and south woods and in the coastal strip, the sunshine oscillates between 145 and 185 hours of sunshine.

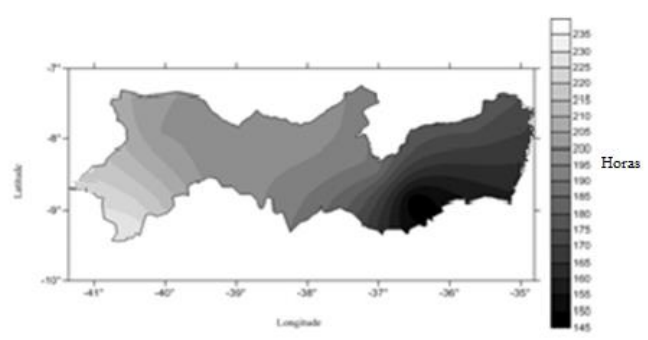

Figure 7. Insolation of the month of June in the State of Pernambuco.

Figure 8 shows the fluctuations of the sunshine of the month of July in the State of Pernambuco. In the coastal region and in the zone of the forest the oscillation of the Insolation varies between 145 and 187 hours. In the central and western regions and at their extremes, the greatest sunshine oscillations are centered with variability of 190 and 217 hours of insolation.

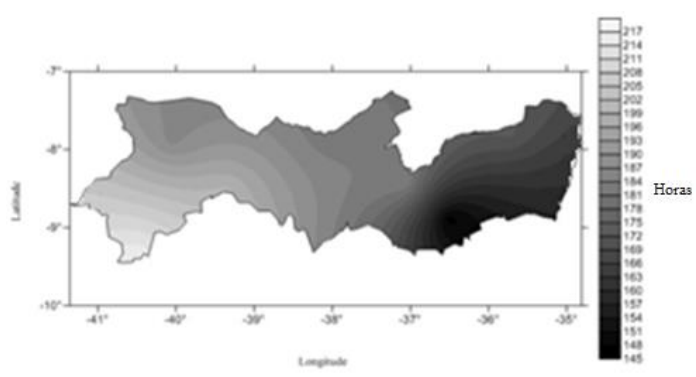

Figure 8. Insolation of the month of July in the State of Pernambuco.

The month of August is considered to receive the highest incidence of sunshine in the central and western areas, while the forest and coastal areas remain practically the same as in the other months of the study (Figure 9).

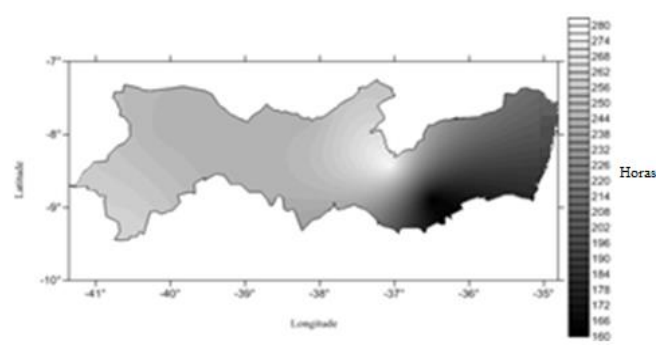

Figure 9. Insolation of the month of August in the State of Pernambuco.

In September, it is noted that in the central area up to the border with CE / PI there was a high incidence of sunshine and in the forest and coastal areas the incidence of sunshine flows between 180 and 230 hours/month (Figure 10).

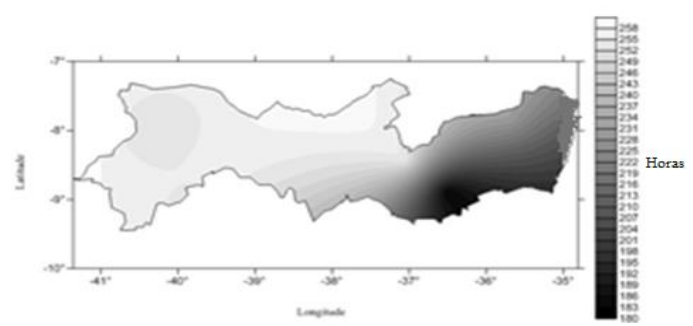

Figure 10. Insolation of the month of September in the State of Pernambuco. 
In Figure 11, corresponding to the month of October, it is observed that the highest incidence of insolation occurs in the southwest region of the state and part of the north region in the border with Paraíba. There is a low incidence of sunshine in the outhern end of the forest zone and in the coastal area.

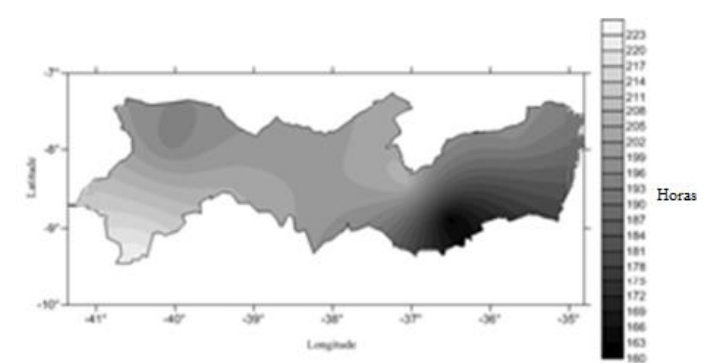

Figure 11. Insolation of the month of October in the State of Pernambuco.

The month of November (Figure 12) stands out due to high insolation rates in the central and northern regions of the state, and the low incidence of sunshine occurred in the west, south and north woodlands and in the coastal region.

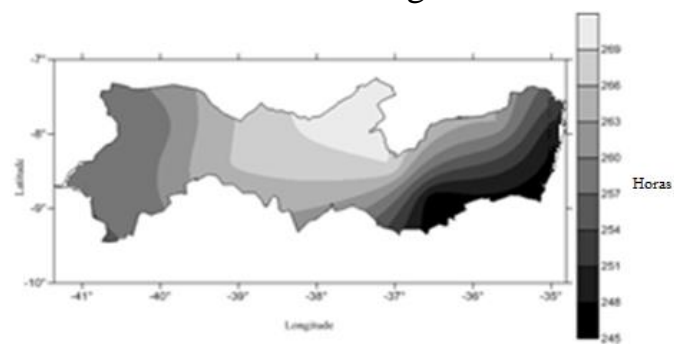

Figure 12. Insolation of the month of November in the State of Pernambuco

The month of December registered the lowest incidence of sunshine in the southeast region of the southern forest zone and variability between the coast and the northern forest zone as well as on the border of Ceará and Piauí. In the central and northern area of Paraíba, the highest sunshine occurred according to Figure 13.

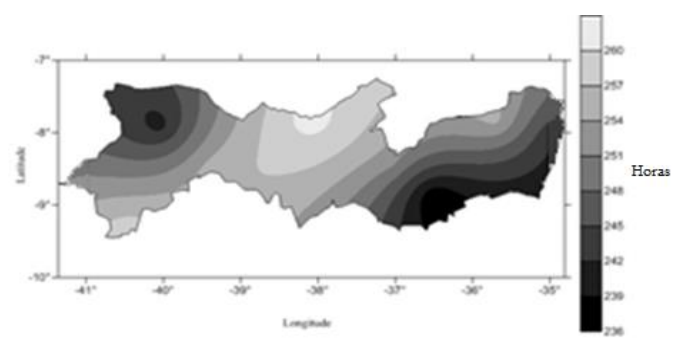

Figure 13. Insolation of the month of December in the State of Pernambuco.
In relation to the annual insolation, the southeast position stands out as the lowest sunshine and with a slight increase in the coastal sector, the northern and southern forest areas. In the western direction, the increase in the incidence of sunshine is highlighted, according to Figure 14.

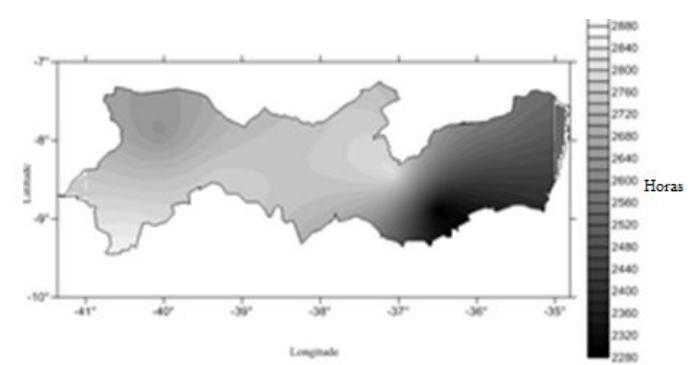

Figure 14. Annual insolation in the State of Pernambuco

Figure 15 shows the average variability in the months of high insolation corresponding to the months of October, November and December in the state of Pernambuco. In the coastal sector and forest area the lowest incidence occurs. As it distances from these areas, sunshine rates increase considerably and are influenced by low cloud cover, above-normal temperature fluctuations, and by burning.

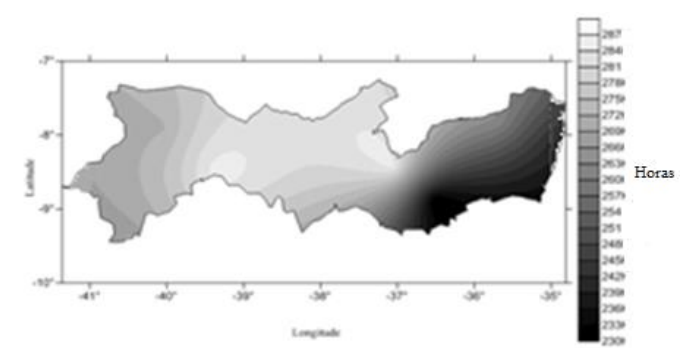

Figure 15. Month of high sunstroke in the state of Pernambuco.

Figure 16 shows the variability in the month of low incidence of insolation (June) that oscillates between 145 and 220 hours. The low incidence of insolation is located in the eastern sector and grows gradually in the central and western sector of the State.

It is highlighted in Figure 17 that in the month of October the highest incidence of insolation occurred in the northern part with the currency of Paraíba and in the central region of the study area. In the eastern and extreme west, the incidence of intermediate insolation is centered. 


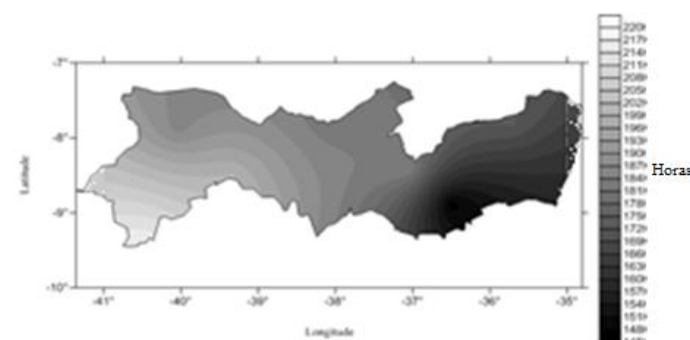

Figure 16. Month of low sun exposure in the State of Pernambuco.

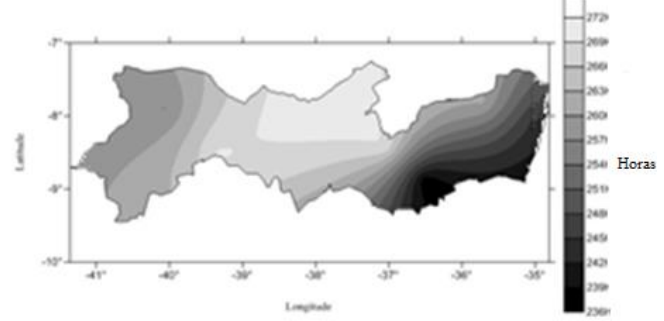

Figure 17. Month of greatest sunstroke in the State of Pernambuco.

Table 1. Statistical parameters of the average insolation for the state of Pernambuco-PE.

\begin{tabular}{ccccccc}
\hline Months & Mean & $\begin{array}{c}\text { Deviation } \\
\text { Standard }\end{array}$ & $\begin{array}{c}\text { Variance } \\
\text { coefficient }\end{array}$ & $\begin{array}{c}\text { Absolute } \\
\text { maximum }\end{array}$ & $\begin{array}{c}\text { Absolute } \\
\text { Minimum }\end{array}$ & Median \\
\hline jan & 232,8 & 9,4 & 0,040 & 242,4 & 235,3 & 224,4 \\
feb & 207,3 & 14,8 & 0,071 & 221,6 & 211,0 & 179,1 \\
mar & 218,6 & 14,4 & 0,066 & 235,0 & 218,8 & 203,5 \\
apr & 209,1 & 17,2 & 0,082 & 229,0 & 212,7 & 203,5 \\
mai & 197,0 & 17,5 & 0,089 & 223,1 & 199,7 & 194,3 \\
jun & 181,2 & 21,3 & 0,118 & 216,6 & 181,9 & 186,2 \\
jul & 188,3 & 25,3 & 0,134 & 231,2 & 199,2 & 199,7 \\
ago & 231,4 & 37,5 & 0,162 & 278,1 & 246,1 & 245,0 \\
set & 237,7 & 27,9 & 0,118 & 259,3 & 259,3 & 252,4 \\
out & 265,6 & 20,5 & 0,077 & 286,1 & 281,4 & 271,6 \\
nov & 259,5 & 9,1 & 0,035 & 269,7 & 269,7 & 258,3 \\
dez & 250,3 & 9,3 & 0,037 & 261,5 & 261,5 & 240,8 \\
annual & 2644,7 & 193,3 & 0,100 & 2861,1 & 2748,9 & 2632,1 \\
\hline
\end{tabular}

Software was used in electronic spreadsheets, for extraction of values of monthly, annual, standard deviation, median, coefficient of variance of precipitation, maxima and minimum absolute values.

The average monthly variability ranges from 181.2 to 265.6 with an annual average of 2,644.7.

Monthly median variabilities indicate that this measure of central tendency may not be the most likely to occur in this type of distribution. It is also notable that the monthly averages surpass the median values in some months. Thus, the monthly sunshine distribution models are asymmetrical, with a positive asymmetry coefficient. Therefore, the median is more likely to occur than the mean.

According to Galvani (2011) the standard deviation is important to have information on the "degree of dispersion of values in relation to the mean value". The coefficient of variance that is used to make comparisons in relative terms and express "the variability of each set of data normalized to the mean, in percentage."

\section{Conclusions}

The incidence of sunshine above normal in the hinterland and upper sertao regions is conditioned by the low incidence of cloud cover, temperature fluctuations above normal and the occurrence of fires.

The method of interpolation of the insolation data by the kriging model presented optimal levels of significance when extended to the other regions of Pernambuco, demonstrating satisfactory climatic conditions similar to the values used in the stations studied;

The kriging of monthly, annual and monthly insolation data, as well as the months of low and high insolation values for spatial distribution maps, can be an alternative to generate reliable estimates and maps of greater representativity.

\section{References}

Alburquerque, I.F., Ferreira, J.N., Silva, M.G., Dias, M.F., 2009.Tempo e Clima no Brasil. Oficina de textos, São Paulo.

Andriotti, J.L.S., 2009. Fundamentos de Estatística e Geoestatística. v.3. Unisinos, São Leopoldo. 
Bayer, C., 2004. Manejando os solos agrícolas para alta qualidade em ambientes tropicais e subtropicais. FERTBIO, Lages.

Bley, JR.C., 1999. Erosão solar: riscos para a agricultura nos trópicos. Ciência Hoje 25, 24-29.

Brito, L.T.L., Moura, M.S.B., Gama, G.F.B., 2007 Potencialidades da água de chuva no Semi-árido brasileiro. Embrapa Semi-Árido, Petrolina.

Galvani, E., 2011. Estatística descritiva mensal de aula, in: Venturi, L.A.B. Geografia: práticas de campo, laboratório e sala de aula. Editora Sarandi, São Paulo.

INMET. Instituto Nacional de Meteorologia, 2016. Normais Climatológicas do Brasil 1962-2016. Brasília.

Medeiros, R.M., 2016. The meteorological factors in the state of Pernambuco.

Pires, C.A.F., Strieder, A.J., 2006. Modelagem Geoestatística de dados geofísicos, aplicada à pesquisa de $\mathrm{Au}$ no prospecto volta grande (Complexo Intrusivo Lavras do Sul, RS, Brasil). Revista Geomática 1.

Santos, R.M.B., 2014. Aplicação do método de kriging para estimar campos de radiação solar: um estudo para o Nordeste do Brasil. Dissertação (Mestrado). São José dos Campos, INPE.

Sediyama, G.C., 1996. Evapotranspiração: necessidade de água para plantas cultivadas. ABEAS/UFV, Brasília. (Curso de Engenharia da Irrigação, módulo 4).

Souza, J.D., Silva, B.B., Ceballos, J.C., 2003. Estimativa da radiação solar global à superfície usando um modelo estocástico: caso sem nuvens. Revista Brasileira de Geofísica 26, 3144.

Souza Filho, F.A., Moura, A.D., 2006. Memórias do Seminário Natureza e Sociedade nos SemiÁridos. Banco do Nordeste do Brasil, Fundação Cearense de Meteorologia e Recursos Hídricos, Fortaleza.

Tiba, C., Fraidenraich, N., Moskowicz, M., Cavalcanti, E.S.C., Lyra, F.J.M., Nogueira, A. M.B., Grossi Gallegos, H. (Coord.), 2000. Atlas Solarimétrico do Brasil. Editora Universitária da UFPE, Recife.

Yamamoto, J.K., Landim, P.M.B., 2015. Conceitos e Aplicações. Oficina de textos, São Paulo. 